How to cite this article:

Sule, B., Mikail, I. K., \& Yahaya, M. A. (2020). An overview of the genesis, sources, manifestations and impact of Small Arms and Light Weapons (SALW) in northern Nigeria. Journal of International Studies, 16, 195-218. https://doi.org/10.32890/jis2020.16.12

\title{
An Overview of the Genesis, Sources, Manifestations and Impact of Small Arms and Light Weapons (SALW) in Northern Nigeria
}

\author{
${ }^{1}$ Babayo Sule, ${ }^{2}$ Ibrahim Kawuley Mikail \& ${ }^{3}$ Muhammad Aminu Yahaya \\ ${ }^{1}$ Department of Political Science, \\ Faculty of Humanities Management and Social Sciences, Gombe State Nigeria, \\ ${ }^{2}$ Department of Political Science, \\ Federal College of Education, Zaria Kaduna State Nigeria. \\ ${ }^{3}$ Department of Public Administration, Faculty of Arts and Social Sciences, \\ Gombe State University
}

${ }^{1}$ Corresponding author: babayosule@gmail.com

\begin{abstract}
The protracted proliferation of Small Arms and Light Weapons (SALW) from around the globe to Africa, specifically in Northern Nigeria, had led to a plethora of social crises that have culminated to the insecurity across the region for more than a decade. Armed conflicts that resulted from the effects of the spread of SALW across the three geopolitical zones in the North had subsequently led to the Boko Haram insurgency in the Northeast, farmers-herders conflict in the Northcentral, armed banditry in the Northwest, and ethnoreligious conflicts and mass kidnappings in the region. The objective of this study is a critical and thorough investigation of the SALW in exacerbating armed conflicts, in general, in the Northern part of Nigeria. The main problems identified in this study are the armed conflicts that have threatened to entirely destabilize the region, and the increased distribution of SALW across the region despite the global efforts to contain their spread for security reasons. This study used a qualitative method of data collection and analysis. Both primary and secondary sources were employed in this study. The primary sources were the interviews conducted with selected informants in the relevant area of study. The secondary sources were the use of available literature on the subject matter. Discussions were carried out by using thematic analytical interpretations. The research discovered that the rampant armed conflicts in Northern Nigeria is the reminiscent of the spread of SALW in the region, which subsequently led to the present critical security situation. Furthermore, weak policies and
\end{abstract}


political institutions had contributed to the spread of SALW, indicating a need for a strong policy approach. This study recommends, among other numerous suggestions, that efforts should be intensified in intelligence gathering to detect the networking of the racketeers in the armed business and contain them appropriately, as well as total blockage of the weapons' distribution routes.

Keywords: Armed conflict, crisis, northern Nigeria, peace, small arms and light weapons, security.

\section{Introduction}

Small Arms and Light Weapons (SALW) are guns, smaller than usual bombs, impelled projectiles and rifles that are utilized for assaults and offensive violent clashes. The SALW are privately manufactured, and are imported from abroad. They are perceived as privately made incorporate bombs, projectiles and guns that are produced locally and are wrongfully held till today. The imported SALW also includes rocket launchers, rocket frameworks, light assault rifles, guns and other related firearms. Small Arms are weapons that can be worked by an individual, while Light Weapons are intended for an aggregate activity or joint use. Light Weapons are more powerful and inconvenient than Small Arms (GIABA Report, 2013:12).

SALW have led to many ramifications on the lives, jobs, future, security and prospects of a large number of individuals over the globe. SALW are correlated with various worldwide security issues, infringement of executives, fear-based oppression, violations, financial advancement, de-radicalization, post-strife recreation, and other issues related to general wellbeing. However, SALW are not government controlled and although these weapons are being utilised by the constituted authorities for protection and security purposes, these weapons have mostly been wrongfully utilised by radicals, outfitted gatherings, psychological militants, ethnic volunteer armies and groups of hoodlums (United States Institute for Disarmament Research, 2006:1).

It is proposed that there are around 100 to 500 million SALW available for use, apart from the other millions that were intended for formal security and non-military personnel use. However, the above figures are speculative, considering the fact that the SALW are not recorded in authority measurements on the arms exchange. This makes it difficult to evaluate precisely, particularly on grounds that they are regularly fabricated. With around 70 nations that manufacture SALW, direct deals from the producers of weapons to remote governments and privately-owned businesses are the main drivers of supply around the world. In any case, such deals are generally directed by national governments. For example, in 1996 alone, the US State Departments authorised over $\$ 470$ million of light military weapons for fare. Surplus weapons after the Cold War is the second main reason that contributed to the SALW supply today. The countries that participated in the War are emptying and limiting the surplus weapons to the worldwide market. The third reason is the clandestine weapon running by governments to outside governments, or guerillas and criminal gatherings (https://fas.org/asmp/battles/smallarms/primer.html). 
UN reports have suggested that these weapons are unlawfully traded, have been distributed by government authorities in numerous nations and pirated into combat areas. Around 59 percent of the SALW are wielded by regular folks, 38 percent are claimed by government military, 2.8 percent by police, and 0.2 percent by furnished gatherings (Worldwide Policy Forum, 2011). Current figures have shown that 640 million SALW are being distributed worldwide, whereby out of this figure, 100 million are situated in Africa for which 30 million are spread or could be found in Sub-Saharan Africa and 10 million SALW are proposed to be in West Africa. The aggregation of these weapons in the region brought about delayed clashes, savagery, philanthropic emergencies and human sufferings over numerous decades (Method, 2018). Nigeria is one of the nations with an overwhelming number of SALW. In 2016, the United Nations indicated that the SALW had essentially expanded in West Africa to around 500 million, whereby 350 million SALW could be found in Nigeria alone. The report inferred that Nigeria is being overwhelmed with illegal weapons that are used by unauthorized citizens of Nigeria (Nwachukwu, 2018).

Northern Nigeria is one of the major hubs for illegal SALW, which are being trafficked through the Lagos border, Cameroon, Niger and Chad borders into the Northern parts of the country for illicit activities. This has been one of the major explanation behind the proliferation of protracted conflicts across the North in recent years. This study is an investigation of the role of SALW on the escalation of armed conflicts in Northern Nigeria. The study area was chosen following a thorough academic investigation which disclosed inadequate examination of this area with specific consideration to the Northern part of the country. The purpose of this study is to complement the knowledge gap in the field as the researchers have clearly identified that there are no such study of this nature that have been undertaken in the study area. Most of the studies obtained were reports and minor data from the international agencies and organisations. This is the first of its kind in a rigorous academic study of the subject matter within the study area.

\section{Literature Review}

In this section, the relevant and existing literature on the subject matter of study are reviewed critically to enable the identification of research gap and contribution to knowledge. The literature was reviewed thematically as follows: Small Arms and Light Weapons: a conceptualization; the global spread of Small Arms and Light Weapons; emergence of Small Arms and Light Weapons in Africa; Small Arms and Light Weapons in Nigeria, emergence, causes and spread; and the legal and institutional responses against illicit trafficking of SALW.

\section{Small Arms and Light Weapons: A Conceptualization}

Small Arms include guns, self-stacking guns, rifles, carbines, sub-automatic weapons, attack rifles and light assault rifles. Light Weapons are substantial automatic rifles, mounted 
projectile launchers, anti-aircraft guns, versatile enemy of tank weapons, rocket framework launcher, compact launchers of against airplane rocket frameworks, and mortars of gauges of less than $100 \mathrm{~mm}$ (Meek and Stott, 2004: 11). Meek (2004) further asserted that Small Arms and Light Weapons (SALW) are all state-held overflow, excess, outdated, unserviceable, seized self-loader and programmed weapons, and reason assembled expert sharpshooter rifles of a bore up to and including $12.7 \mathrm{~mm}$.

In addition, Small Arms are considered as 'any man-made convenient deadly weapon that ousts or dispatches, is intended to remove or dispatch, or might be promptly changed over to remove or dispatch a shot, and slug or shot by the activity of an unstable'. These include guns, self-stacking guns, rifles, carbines, sub-automatic weapons, attack rifles and light assault rifles. Light Weapons are considered as weapons structured by a few people that are comprised into teams, albeit some of them might be used by a single person. Moreover, they utilize automatic rifles, hand-held under barrel, mounted explosive launchers, compact enemy of air ship firearms, versatile enemy of tank firearms, launchers of hostile to air ship rocket frameworks and mortars of gauge of under $100 \mathrm{~mm}$ (Central African Convention for Control of Small Arms and Light Weapons, 2011). The above classification indicates that Small Arms differs entirely from Light Weapons in their tendency, reason and activity. Small Arms are normally individualistic, while Light Arms are operational for gathering purposes, and for aggregate use and strike.

SALW are weapons that are worked independently, or all in all for both lawful and unlawful purposes. They incorporate guns, self-stacking guns, rifles, carbines, sub-automatic weapons, strike rifles, light assault rifles, overwhelming assault rifles, hand-held under barrel and mounted explosive launchers, versatile enemy of air ship firearms, convenient enemy of tank firearms, recoilless rifles, compact launchers of hostile to tank rocket and rocket frameworks, convenient launchers of against airplane rocket frameworks, and mortars of bores of under $100 \mathrm{~mm}$. related ammo and explosives are considered the main component that are classified under the little arms class. In contrast with real weapon frameworks, Small Arms are shoddy, effectively accessible, easy to work, versatile, and simple to fix or supplant. Small Arms and Light Weapons are worked by state on-screen characters legitimately and other universal offices. However, it is suggested that out of the current 640 million SALW around the world, about $60 \%$ are being used unlawfully by outfitted gatherings, radicals and culprits. The global network is tending to the Small Arms issue from different angles of the free market activity. On the supply side, attempts have been made to observe and improve parties involved in the manufacturing, amassing and exchange of Small Arms. On the demand side, efforts have been made to identify and understand the intentions of those looking to procure the weapons (United Nations Institute for Disarmament Research, 2006:2).

Small Arms are distinguished as weapons intended for individual use, and includes light automatic weapons, sub-automatic rifles, guns, completely programmed rifles and ambush rifles, and quick firing rifles. Little Arms incorporates guns as rocket launchers and are 
convenient to remove assaults. Little Arms additionally comprises of ammo including cartridge cases, preliminaries, force powders, slug or shots that are utilised in a Small Arms or Light Weapons. Light Weapons are weapons that are intended for use by a few people within groups, substantial assault rifles, programmed guns, howitzers, mortars of under $100 \mathrm{~mm}$ bore, projectile launchers, against tank weapons and air safeguard weapons (Saferworld, 2012:2).

A large portion of the global associations and offices have agreed upon the above definitions and characteristics of SALW the degree that the conceptualization of these weapons can be authoritatively perceived universally. For instance, the United Nations Development Program, Economic Community of West African States (ECOWAS) and other universal bodies acknowledged the above examined significance of SALW.

\section{The Global Spread of Small Arms and Light Weapons (SALW)}

Small Arms and Light Weapons (SALW) are available for use on the planet today like never before, and are legitimately connected with conflicts and disputes in many parts of the world. For example, in the United Nations Conference on the issue to combat the spread of Small Arms and Light Weapons under the support of the Security Council Debate, Francois Delattre, a delegate of France and a partner of the European Union, expressed that there are exactly 800 SALW available for use and have been linked to about 90 percent of casualties from these clashes. He further asserted that the spread of SALW is increasing, and the unlawful dealing of those weapons was a test to advancement in numerous delicate states. During the opening statement of the session, David Pressman, a delegate from the United States of America, had highlighted that the moderate gauge of exchange of SALW was assessed at \$1 billion every year, with black market dealings representing an extra \$200 million (United Nations, 2015).

In 2015, the Security Council revealed that Small Arms does not only take lives, but it also disrupts economies and the social bonds on which each sort of aggregate organisation and advancement is dependent upon. These are the weapons of the simple murder, the most compact, most effectively open, most easygoing instruments of death. The most exceedingly terrible human brutality was likewise helped by the accessibility of arms. The UN Secretary General, Ban Ki Moon, emphasized that overall accessibility of weapons was considered the main cause of more than 250 clashes in the past decade that has led to more than 50,000 death every year, with records levels of displacement (United Nations, 2015).

During the Security Council meeting, the President of Cote d'Ivoire, Karamoko Diakete, had described the fear that his nation experienced during discretionary savagery when gatherings were appropriated using SALW by legislators. Thousands were executed and the complete expense was incalculable. It was deduced that after the evacuation of Mu'ammar Ghaddafi in Libya, SALW was subsequently distributed and exported to the Sub-Saharan Africa to sustain fear mongers, particularly in Mali, Niger, Nigeria, Chad and Cameroon. 
The delegate of the Chinese government, Lie Jieyi, asserted that the manufacturing and distribution of SALW, just as the beginning of new innovation, had made a hazardous worldwide circumstance. The delegate of the Russian Federation, Petr Iliichev, stated that his nation was a product of the developing expansion of SALW which were utilised by psychological militants and unlawful outfitted gatherings. He proposed that the various states must come together under United Nations Program of Action on Small Arms and Light Weapons to curb this problem (United Nations, 2015).

The delegate of Chad, Mahamat Zene Cherif, indicated that his nation have been suffering from the negative impacts caused by SALW, and had endured far reaching passing, barbarities and dislodging. Additionally, the Nigerian delegate, U. Bliss Ugwu, asserted that his nation was tormented by conflicts due to the simple accessibility to SALW. The delegate of Spain, Roman Oyarzun Marchesi, suggested that SALW had caused the most astounding number of deaths in present day times and are one of the reasons for increment in fearbased oppression today. The casualties of the unlawful exchange were mostly women and children, and were subjected to sexual brutality, terrorist fighting or even kidnappings. Rafael Damiro Ramirez Carreno from Venezuela, has indicated that the enormous preoccupations of weapons had exacerbated clashes and infringement of human rights, especially in Middle East and Northern Africa. Ismael from Angola portrayed that the genuine results of enabling access to SALW had led to psychological warfare and developed an extensive criminal system around the world. Raimonda, the delegate from Lithuania, stated that the unlawful exchange and spread of such weapons all-inclusive had led to approximately 500,000 deaths every year through constrained removal, assault, child enrollment by outfitted gatherings into terrorist group, and annihilation of men, women and children in networks far and wide (United Nations, 2015).

Small Arms and Light Weapons are marketed across the world in both legal and illicit processes by both the state and non-state actors. The category of such weapons consist of guns, pistols, AK 47, machine guns, automatic guns, rockets, rockets launchers, antiaircraft guns, grenades, Rocket Propelled Grenades (RPGs), improvised explosive devices (IEDs) and other classified ones under this group that could be handled by an individual, two persons or a smaller group of people (SIPRI Year Book, 2019). Global arms market share increased profoundly in 2018 compared to the past year (2017), which is more than its spread during the Cold War era. Arms trade between 2009 and 2013 were 23 percent higher than in the period between 2004 and 2008. Between the period of 2014-2018, arms trade attained its peak since the end of the Cold War. In 2018, SIPRI reported that the total global arms trade in 2017 was valued at \$95 billion, while weapons export was valued at \$27.6 billion (Durkin, 2019).

The official or legal sales of arms and its trade is very complex and difficult to be tracked as it sometimes takes place under covert arrangement, owing to critical matters of national security. The United States and Russia dominated the global arms trade deal. According to SIPRI (2019), 202 states, 48 non-state armed groups, and five international organisations 
were supplied with arms shipment between the years 2013 to 2018. The United States, Russia, France, Germany and China are the major global exporters that accounts for 75 percent of the total world exports. The US and Russia alone had constituted for 57 percent of the total global share in arms trade. The five largest global exporters were Saudi Arabia, India, Egypt, Australia and Algeria, and accounted for 35 percent of the total global arms import from the year 2014 to 2018 (Durkin, 2019).

The following figure illustrates the global arms trade exports in the year 2018.

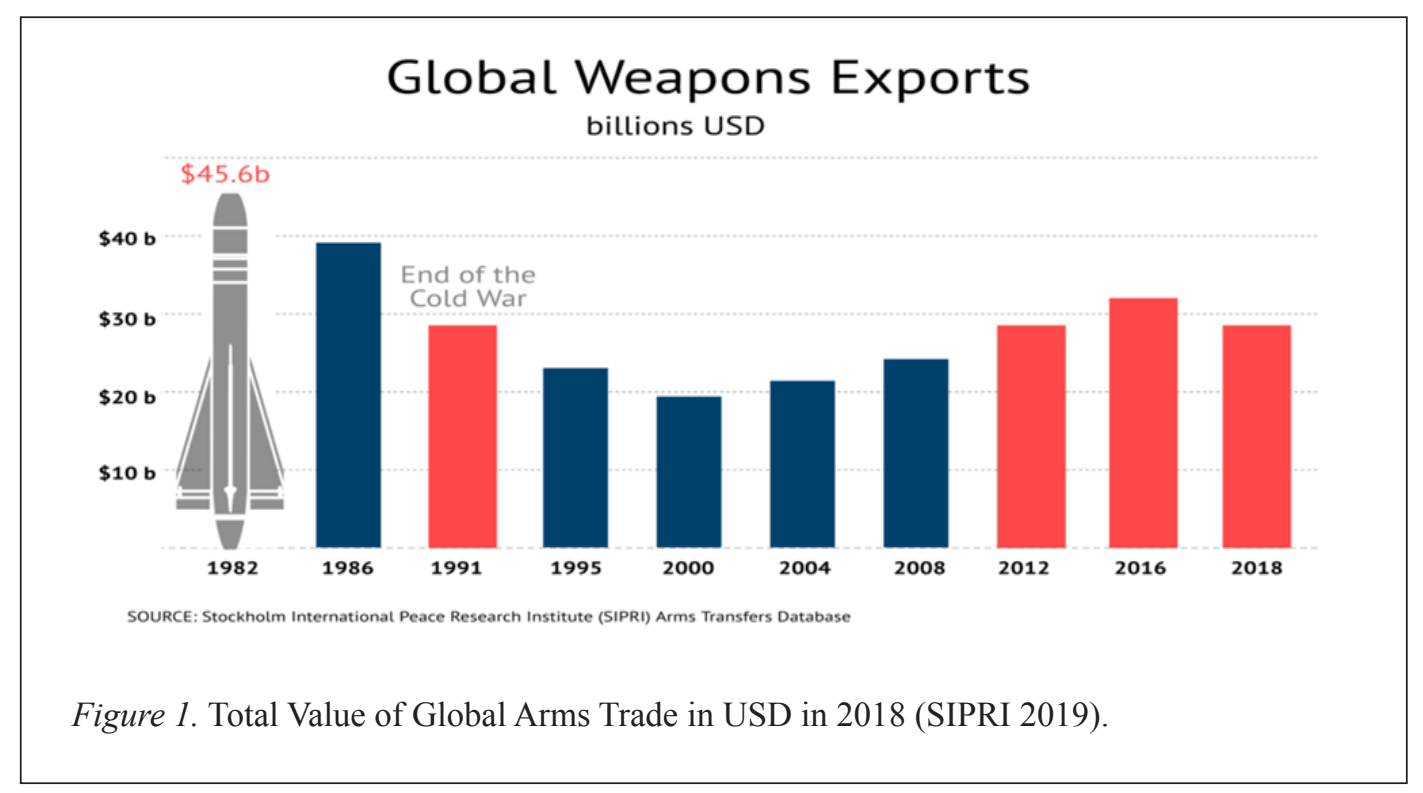

\section{Emergence of Small Arms and Light Weapons (SALW) in Africa}

The main cause that led to the rise of SALW in Africa is unlawful dealing. Africa is perhaps the greatest mainland with sea and land fringes, permeable outskirts, wildernesses and broad forsakes which has made it simpler for dealing weapons into the outskirts of the other African nations. This is on grounds that it is hard to discover any state or landmass on the planet that is able to viably control such broad fringes (Yacubu, 2005: 57). Domestic arms production is another factor that prompted the spread of SALW in Africa in recent times (United Nations Institute for Disarmament Research, 2002). During the 1980s, the degree of arms manufacturing in Africa was negligible. However, with the subsequent development of supported extended ethnic civilian armies, ethnoreligious emergencies, equipped dissident gatherings, groups of thugs, fear based oppressors and religious radicals, the arms manufacturing had soared, which led to disputes and clashes across the region especially in Sub-Saharan Africa (Ohene-Asare, Aklavon, Mossou and Ikelegbe, 2014:3).

The illicit trafficking of Small Arms in Africa was reported to have been more than any other region in the world due to its weak political institutions, porous national borders and 
protracted armed violence and conflicts in many countries across the Continent. Small Arms were linked to a multitude of Africa's security concern reminiscent that had eventually caused armed conflicts, violent extremism, organised crime, and community and domestic violence (Alusala, 2016). After the removal of Ghaddafi in Libya, a vehement route for the illegal transfer of SALW was established that led to an influx of Small Arms in SubSaharan Africa. This further increased and extended the volatile security situation in the region due to various armed group conflicts. Several African countries were embroiled in insecurity challenges and armed group conflicts due to the access to illicit weapons by many armed group terrorist in the Continent. The Trans-Saharan route thus, became the most challenging issue when addressing the flow and spread of Small Arms in Africa. Out of the estimated 650 million Small Arms in Africa, about 540 million was believed to have been distributed in Sub-Saharan Africa, with Nigeria having possess nearly 70 percent of the total weapons (Nowak \& Gsell, 2018). With the current socioeconomic and political volatility in the region, armed group conflict is inevitable. The region is the poorest, with the highest number of youths that are unemployed, jobless, poor, deprived, educationally disadvantaged. As healthcare service delivery has become inadequate, carrying guns and Small Arms for violent conflict is the type of response by the restive and dissatisfied youth in the region.

There are many illegal arm groups and terrorist groups in Africa that are wielding SALW in their combats. The Al Shabab in Somalia, Al Qaeda in Mali, Boko Haram in Nigeria, Niger, Chad and Cameroon as well as Al Qaeda in the Maghreb (AQIM) are some of the groups that were established pursuant to the consequences of the illicit global flow of weapons in West Africa. These groups have caused severe socioeconomic crises and political upheavals that have crippled the states in the region for many decades. The crisis continues to erupt in various parts of Africa. From ethnic violence and armed conflicts in Rwanda, Sierra Leone, Liberia, Sudan, Central African Republic, Democratic Republic of Congo, Congo Kinshasa, Ethiopia, Kenya, and Nigeria during the 1980s and 1990s, the armed group violence took a new dimension of civil unrest and uprising in the African-Arab world in 2011, particularly in Tunisia, Egypt and other Middle-Eastern Arab countries. The modern armed group conflict has now became associated with terrorism and armed violence in several parts of the Continent due to the distribution of Small Arms (Method 2018 and Nowak et al. 2018). The conflicts that emanate from the spread of SALW in Africa continues unabated. For instance, Maeresera, Rugeje \& Zengeni (2018) suggested that SALW is the main factor in the defiant nature of Congo's armed conflict for many years, up to 2017. In another view, Mukhtar, Che Rose, Choy \& Bibi-Farouk (2018) proposed that Boko Haram in Nigeria was able to terrorize the country that led to force migration, as a result of the use of IEDs and other SALW which they have acquired through the illicit route of transfer and marketing. The picture below shows the route for the flow of weapons in Africa.

Some regional and multilateral organisations have already established measures to combat the spread of illicit arms. The Organisation of American States (OAS) Inter-Amercian Drug Abuse Control Commission (CICAD) agreed on the model regulations to control brokers 
of small arms. In Africa, the brokering of SALW has been made by all the African Union members including the horn of Africa (the Nairobi Group), the Southern African Development Community (SADC) and the Economic Community of West African States (ECOWAS). Although the agreements in Africa are legally binding, the majority have yet to incorporate these standards into their domestic law. In Europe, the standard for the control of brokering of all conventional arms were agreed upon by the European Union and the Organization for Security and Cooperation in Europe (OSCE). The European Union initiated a process for the control of air transport of illicit weapons to minimize the weapons distribution to the hands of undesired targets (International Peace Research Institute; SIPRI, 2009). The Asian and Middle East regions have not established any measures to control arms brokering, however, the Association of South East Asian Nations (ASEAN) had made explicit efforts in 2002 to prevent arms smugglings as part of transnational crime. In 2004, Asia Pacific Economic Cooperation (APEC) agreed to ban the use of non-governmental brokers and brokering services for transfers of man-portable air defense systems (MANPADS) (United Nations, 2006). In Africa, the challenge of regional integration and border management cooperation have been the major obstacle towards monitoring and stopping the spread of crimes and weapons in the Continent for several decades (Aboyade, 2018). The study carried out by Aboyade (2018) suggested that the events pre-1945 Europe should be taken into consideration as a cue towards overcoming this identified challenge.

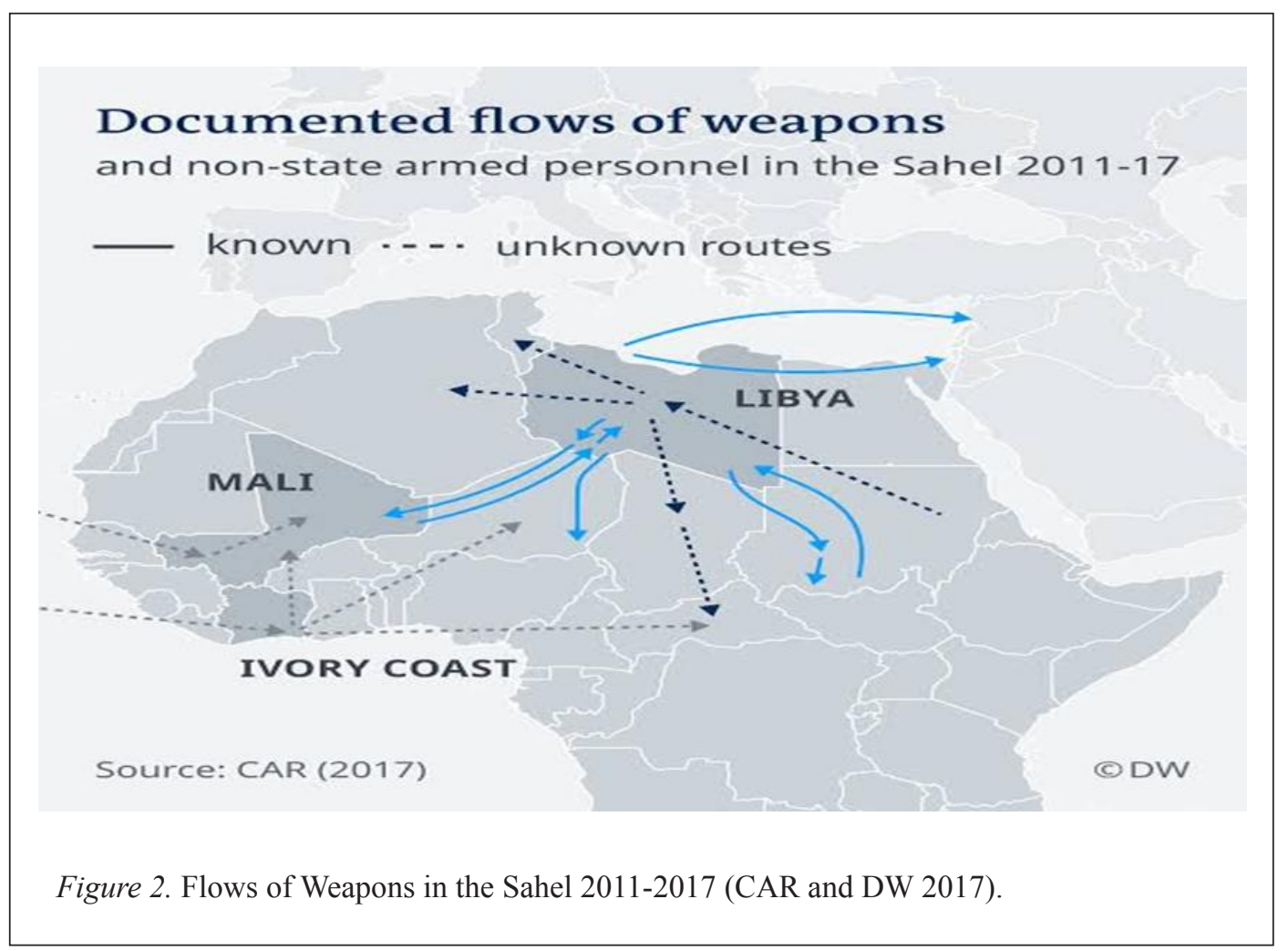


The global spread of SALW has not been unaccompanied with containing measures to address the problem at the international and regional level. There have been various measures, approaches and actions that were designed and adopted by all stakeholders to manage the security issues that could curb the illicit spread. For example, one of the measures that were undertaken by South Africa was to establish an institution that was responsible for identifying illicit weapons and destroying them to avoid further illegal transfer and ownership. The South African National Conventional Arms Control Committee (NCACC) took a bold step to destroy all state-held redundant, obsolete, unserviceable and confiscated semi-automatic and automatic weapons of a caliber up to and including 12.7 $\mathrm{mm}$. The policy was implemented by the South African National Defense Force (SANDF), where 260,000 small arms have been destroyed as part of operation Mouflon (Mock \& Stott, 2004:1).

Another effort was also carried out by the Central African Convention for the Control of SALW. The Convention identified SALW and established provisions under Article 3 of the Convention that specified the authorization of transfers to state, Article 4 that prohibited transfer of weapons to non-state armed groups, Article 5 which provides the means and procedures for the issuance of transfer of authorization, and Article 7 that prohibits ownership by civilians to avoid the emergence of armed groups (Central African Convention for the Control of Small Arms and Light Weapons, 2011). Furthermore, the United Nations had also established measures to combat the proliferation of SALW in West Africa by providing the logistics for training of state armed and security forces on the identification of the illicit weapons, tracing, marking, destruction and prevention of the spread (Ayissi \& Sall, 2005).

There are several regional efforts to control the spread of illegal weapons. The European Action on Small Arms and Light Weapons (EASALW) in its final report in 2006 presented giant steps towards identifying, tracing and prohibition of illegal sales (United Nations Institute for Disarmament Research, 2006). The regional analysis and national reports during the five year of its implementation of the United Nations Programme of Action on Small Arms and Light Weapons indicated that although a remarkable achievement has been achieved, there was still more to be achieved with regards to collaboration between countries and regions (Kytomaki \& Yankey-Wyne, 2006). The United Nations have guided states on the ways to establish the required legislation on SALW to ensure compliance and effectiveness (United Nations Development Programme, 2008). Countries were guided on marking of SALW to ensure that they are easily traceable, and would enable the quick identification of the illicit weapons (Ashkenazi, Beeck \& Isikozlu, 2007). One of the best policy alternatives that was identified in the prevention of Small Arms and Light Weapons (SALW) was to prevent diversion by nation-states, manufacturers, multilateral organisations and agencies (Greene \& Kirkham, 2009). Gikonyo (2012) and Gathaga (2015) argued that most of the East African countries had signed a ratification for the control and prevention of the proliferation of SALW to ensure and guarantee safety, and security in Eastern Africa.

The United Nations provided the necessary measures to assist in the identification and tracking of the illicit SALW effectively. The organization also provided programs of action to prevent, combat and eradicate the illicit trade in SALW. This has been done through 
various protocols against the illicit manufacturing and trafficking of firearms, their parts, components and ammunition that supplement the United Nations Convention against Transnational Organized Crimes and other UN resolutions that have been ratified into law (United Nations Institute for Disarmament Research, 2008). However, Bourne (2007) emphasized that the neglect of regional level by the authorities concern is the major problem with the policies, programmes and legal institutions when controlling the proliferation and spread of SALW.

Efforts were also taken to control the global flow of Small Arms by Intelligence Agencies which provide any relevant information, Stockholm International Peace Research Institute (SIPRI) which monitors, registers and takes statistics of arms transfer and flow across world countries, Norwegian Initiative on Small Arms Transfer (NISAT) which tracks governments legal transfer of Small Arms and Light Weapons, and the United Nations Panel of Experts which monitors data and assesses it based on arms transfer under the full or partial UN arms embargo (Wezeman 2018, Holtom \& Pavesi 2018 and Freeman 2018). Despite all these measures that have been established to protect the proliferation or illegal transfer of weapons especially to arms groups, the SIPRI Year Book in 2018 reported that over 42 armed groups continued to receive Small Arms from the black market. In addition, the SIPRI 2019 further reported that the illicit arms trade in Small Arms in parts of Africa, Eastern Europe, Asia and South America continues unabated. This has further compounded the global security threats from armed militia groups, terrorists' groups, political thugs and armed bandits who have secured these weapons easily from a covert and illicit source for their crimes.

There have been studies conducted on SALW in Nigeria, however, these studies were inadequate in examining and analyzing the effects on armed group conflicts in Northern Nigeria specifically. For instance, studies have been carried out on the proliferation of arms and security challenges in Nigeria (Olayiwola, 2017), effect of proliferation of Small Arms and Light Weapons on the development of the Niger-Delta region of Nigeria (Eloma, Ugwumba \& Abang, 2014), human security under threats: the proliferation of small arms in Nigeria (Waziri, Mat \& Taya, 2018), proliferation of Small Arms and Light Weapons: the bane of human security in Nigeria (Olamide \& Emanuel, 2018), Small Arms and Light Weapons proliferation and its implications for West African regional security (Malam, 2014), and Small Arms and Light Weapons proliferation in the $21^{\text {st }}$ century: the Nigerian case (Moses, 2017). However, the aforementioned studies did not explore the implications of SALW from the perspective of the area of study; Northern Nigeria. Therefore, this is the distinguishing feature of this work, and its unique contribution in the discourse of the subject matter.

\section{Theoretical Framework}

This study adopted two major theoretical frameworks to explain the context of the literature, discussion and findings. The theories are: 'Securitisation Theory' and 'Social Conflict Theory'. 


\section{Securitisation Theory}

A new security debate emerged in the 1970s and 1980s, which was principally proposed by Barry Buzan in the field of strategic studies. The Copenhagen School led by Buzan propounded a new paradigm shift in security discourse that was beyond the conservative traditional realm of security discourse. During pre-World War II, security dialogue was dominated by traditional/military debates, while the potential threats to world peace and security were only perceived as military conflicts. However, after the Second World War, a new dimension was introduced and the debate was expanded and consolidated by Buzan (1983) with the full inclusion of non-traditional security threats as equivalent to the traditional threats on world peace and security.

The political, economic, social, environmental and human needs are considered as vital aspects of security as these could constitute to the potential risk to insecurity, similar to conventional military threats if they are not protected (Buzan \& Hansen, 2009:2). Political issues such as ethnic politics, lack of social cohesion, political violence, subversion of democratic process and national question could threaten the peace and security of a community or a state at large. Economic issues that include underdevelopment, inflation, mismanagement, low level of industrialization and low productivity are economic threats that can lead to insecurity in the society. Social problems are another dimension to nontraditional security threats such as corruption, poverty, unemployment, disease, hunger, malnutrition, inequality and gender violence. Moreover, they can constitute to the potential risk and could threaten peace and security in the affected societies. Environmental hazards which include man-made and natural disasters can cause serious security dilemma such as pollution, overcrowding, overpopulation, flood, drought, desert encroachment, deforestation and other related natural phenomenon. These issues could cause a security crisis, similar to traditional/military threats. Buzan (1983) concluded that security discourse should be divergent and must be looked into from dual perspective. Any attempt to narrow security threats to only military would be wrong and insufficient as non-military threats were observed to be more dominant in the contemporary world.

This theory clearly explains the context of this study as the proliferation of Small Arms and Light Weapons (SALW) in Northern Nigeria is correlated with the systemic failure of the policymakers to improve the standard of living of the people in the region. People in the North are in abject penury, impoverishment, malnourishment, sufferings and economic hardship despite the affluence nature of the country. The unemployed restive youth were made an easy prey for recruitment into armed groups and criminal activities because of the social, political, economic and environmental security threats.

\section{Social Conflict Theory}

The theory of Social Conflict has its philosophical roots from the works of Karl Marx. The theory proposes that in every society, there is a competition and struggle for the control of 
resources from different classes that leads to conflicts of interest. 'Social Conflict Theory' is based on the struggles to gain power, resources and interest that have been identified as some of the major causes of conflict in the society (Egbuta, 2018). According to Karl Marx, the competing classes struggle for the scarce resources in the society, and the struggles are so intense that conflict is inevitable due to exploitation and domination of one class by the other in the process. The ruling class that has access to the superstructure are able to perpetuate their economic interest and keep the proletariat class in a perpetual subservient conditions indefinitely.

In Northern Nigerian context, social conflict is inevitable as assumed by Marx due to the nature of the Nigerian economy and politics. Access to political power has been turned into a struggle for wealth accumulation and self-enrichment. The working class have been neglected, subsumed, dominated, exploited and impoverished, which has led to hopelessness and fear. The implication of this action suggested that the working class and the peasant were subjected to a critical situation in which they are compelled to take arms and establish criminal ventures to survive from poverty and economic suffering.

The two theories above are adopted and integrated to explain the context of this study because the emergence of Small Arms and Light Weapons in Africa and Nigeria in particular is the result of political weakness from the ruling class, economic and social emasculation of the masses, and the daunting challenge of environmental hazards in the country that is considered non-traditional security contexts which have led to the class struggles across the region. In their quest for a better life, the armed groups have utilized their leverage of possessing arms to stage violence and upheavals in Northern Nigeria.

\section{Method of Data Collection and Analysis}

This study had employed both primary and secondary sources of data. A qualitative approach was adopted as the research design for the data collection and analysis. The primary source was an in-depth interviews that were conducted with some selected informants that are relevant in the subject matter of study, and are in possession of vital first-hand information on the field of study. The informants were selected from five major categories. The first category is the security personnel, whereby four (4) senior security officials were interviewed from the military and paramilitary based on accessibility by the researchers. The second category is senior officials from the Ministry of Defense, whereby three (3) informants were interviewed from the Defense Headquarters in Abuja based on the officers that are directly related to the subject of study. The third category is the academicians, whereby four (4) informants were interviewed from reputable Northern Universities who are specialist in the field of security and strategic studies. The fourth category is international donor agencies that are operating in Northern Nigeria within the study area such as Save the Children, UNICEF and others, whereby four (4) informants were interviewed in this category based on proximity and accessibility by the researchers. The last category is the civil societies, 
whereby five (5) members from different civil society organisations were interviewed in Abuja. A total of nineteen (19) informants were interviewed for this study.

The interview questions were designed in a semi-structured format to allow for flexibility of responses. The questions were designed differently for all the categories, and were dependent on the nature of information that each informants were expected to provide. Direct and implicating questions were avoided. The interviews were conducted under the oath of confidentiality against any disclosure of the informants for security purpose and for ethical value of research.

The secondary sources consisted of books, journals, internet sources and reports from agencies and international organizations. Various government policies were also examined, particularly on the global efforts by nation-states and international security agencies, African nation's responses and the efforts undertaken by the Nigerian government in combating the spread of illicit SALW within the country. This source was used for the critical review of literature and to establish the theoretical framework that would enable the proper identification of research gap and contribution to knowledge.

The data obtained from both primary and secondary sources were discussed using thematic analytical interpretation, where some themes were formed based on the responses from the informants, and past information and knowledge on the field.

\section{Discussions and Findings: The Role of Small Arms and Light Weapons (SALW) in Exacerbating Armed Conflicts in Northern Nigeria}

In this section, the data obtained from the field were presented, analysed, discussed and interpreted using sub-themes, for which the existing literature were connected with the research findings and strengthened by the adopted theoretical framework.

\section{The Boko Haram Phenomenon in Northeastern Nigeria}

The Boko Haram insurgency is one of the deadliest insurgent and armed groups to have ever operated in Africa. The Boko Haram insurgency affected nine states in the North and the FCT Abuja with all the six Northeastern states of Adamawa, Bauchi, Borno, Gombe, Taraba and Yobe, while Kano, Kaduna and Plateau in the Northwest and Northcentral states respectively have also been affected by the actions of this militia group. The group was established in the early 2000s in Borno and Yobe states as a radical movement that eventually turned into a full armed group by 2009 after the extrajudicial killing of their leader, the late Muhammad Yusuf. The group then later shifted into an insurgent group that have attacked and killed security personnel, civilians, foreign aid workers and other civil groups (Bowser \& Sanders, 2012). Apart from the poor socioeconomic and political condition, poverty, unemployment and ignorance in Northern Nigeria, Forest (2012) 
suggested that the emergence of Small Arms and Light Weapons (SALW) in the region was one of the major causes for the insurgency.

The Boko Haram insurgency in 2014 had gained control of about 20 local governments in Borno, Yobe and Adamawa states, which constituted to nearly 30 percent of the Northeastern region. The group was heavily armed with SALW such as pistols, AK47, machine guns, semi-automatic machine guns, propelled grenades, anti-aircraft guns, anti-tank guns and explosives. They attacked and killed soldiers, police and other security personnel, and have attacked civilians in the mosques, churches, markets, city centers and even in their residences. Nigeria was ranked $3^{\text {rd }}$ in the Global Terrorism Index in 2018 due to the rising terrorism by the Boko Haram insurgency. The Boko Haram insurgency created a serious humanitarian crisis in Northeastern and Northern Nigeria at large, with IDPs being estimated at 2.5 million, and mutual suspicion between Christians and Muslims in the country had started to emerge (Omotosho, 2015).

In the field survey where interviews were conducted with the selected informants, all of the informants had agreed that the spread of illegal arms and dangerous weapons across SubSaharan Africa is one of the major factors that motivated the emergence and spread of the Boko Haram armed groups. Specifically, one of the informants disclosed that; "The escape route for illicit weapons through the Trans-Saharan ways after the collapse of Libya paved the way for the dreaded Boko Haram insurgents to have easy access to illegal weapons for attacks and defense. Not only an easy access, this also offered the chance for the insurgents to establish a network which enabled for training in the manufacture and manipulation of Small Arms and Light Weapons (SALW). The resultant effect is the fact that today Boko Haram is one of the deadliest armed groups in the world reminiscent of arming of criminal movements and insurgents".

Additionally, the Securitisation Theory which advocates non-traditional security such as poverty, unemployment and critical socioeconomic condition, as well as the Social Conflict Theory which explains the nature of struggles and competition to control scarce resources leading to conflict are all applicable and could be interpreted within this context. This is because the Boko Haram insurgency fall within the category of the poor impoverished in Northeastern Nigeria, as they have been competing for power with the ruling elites through violent protests and skirmishes.

\section{Farmers-Herders Conflict in Northcentral Nigeria}

Farmers-herders conflict is another security challenge faced by Northern Nigeria today, especially in the Northcentral region where this conflict has started to become more deadly. Farmers-herders conflict is not a new security phenomenon in the Nigerian history as it was believed to have started in the 1970s. But the crisis escalated after the spread of illicit weapons in Northern Nigeria in recent years. The farmers-herders conflict took a new dimension with the possession of deadly weapons by the two warring groups, which 
subsequently had led to disastrous attacks and the destruction of lives and properties. This is because the accessibility to Small Arms and Light Weapons were made easier and tenable due to undetected brokering, cheap rates, and poor marking and tracking system (Institute for Peace and Conflict Resolution, 2017).

There are numerous factors that were attributed to the emergence of farmers-herders conflict such as ineffective agricultural policies, lack of modernization, politics, socioeconomic condition in the country, climatic changes, abuse of resources, and media sentiments. Other factors include the nature of Nigerian borders which are porous, which enabled illegal smuggling of illicit weapons into the region and was utilized by both the farmers and herders (Kwaja \& Adelehin, 2017). The farmers-herders conflict is one of the deadliest conflicts that have claimed hundreds of thousands of lives, and have destroyed properties that are worth billions in Naira, Nigeria for many decades. For instance, a BBC Report claimed that over 50,000 deaths were caused by the crisis between the years 2001 to 2004. Of these deaths, women and children had accounted for over 35,000. The economic cost that resulted from the farmers-herders conflict in only four states, i.e. Benue, Kaduna, Nassarawa and Plateau, was estimated to be about $\$ 14$ billion annually (Nwosu, 2017). The above estimates were considered in a short-term period. If the period of 2004 to 2019 is taken into consideration, where the crisis had reached its peak, this study estimates that over one million lives have been lost, and an economic cost worth $\$ 150$ billion had resulted in these four states alone.

Similarly, most of the interviewers revealed that the farmers-herders conflicts intensified in Northern Nigeria courtesy of the proliferation of Small Arms and Light Weapons (SALW) in the region for several years. For example, one of the informants narrated that; "the conflict between the farmers and herders is one of the serious security challenges that Nigeria is currently battling with. This has been aided by the rampant and quick spread of Small Arms and Light Weapons easily accessbile, utmostly non-traceable, illegally possessed and technically dangerous allowing for reprisal attacks and counter-attacks. This has been devastating claiming hundreds of thousands of lives and properties worth billions of Naira". Other informants had also shared similar views.

Theoretically, the 'Securitisation Theory' and 'Social Conflict Theory' can be applied in this perspective as the threat to survival was identified to be one of the reasons that led to the possession of the arms that instigated the conflicts. The struggle for supremacy to control the grazing land between the farmers and the herders was a contributing factor that led to conflict.

\section{Cattle Rustling and Armed Banditry in Northwestern Nigeria}

Banditry and cattle rustling is another security dimension that emanated from the possession of Small Arms and Light Weapons (SALW) in Northern Nigeria, particularly in the Northwest. About 58,801 cattle were rustled by armed bandits in Northern Nigeria, where 
300 lives were lost from the violence as reported by Sunday Trust on June 1, 2014 (Egwu, 2016:26). The underlying causes of the banditry were attributed to unemployment, ethnoreligious conflict, greed, robbery, insecurity and psychological needs. The rising incidence of cattle rustling and armed banditry may also be attributed to the problem of Small Arms and Light Weapons (SALW) that have found their way into the hands of non-state actors. The problem of cattle rustling and armed banditry in Northwestern Nigeria has worsened due to the increased distribution of SALW in the communities and regions affected by conflict, especially in the African Sahel region. The proliferation of arms within the region is caused by the lack of successfully-implemented disarmament programmes (Egwu, 2016:47).

Armed banditry has started to become a major issue during the past five years in Northern Nigeria. This has resulted in many negative consequences on the populace in this region. Failure of the state is one of the major contributing factors. The states' failure on establishing the necessary policies had opened up the opportunity for armed groups and criminals to possess lethal weapons for their illegal activities that have been undetected in the affected areas. Many villages in Birnin Gwari, Shinkafi, Maru, Tsafe, Sokoto, Katsina and Birnin Kebbi were wiped out by the bandits, and thousands of lives have been lost. The economy in these areas were shattered as the major means of survival; farming, has been halted for over four years (Kusa \& Salihu, 2016:112). It has also become increasingly common for armed bandits to be disguised as Fulani herders that would wreak havoc in several communities within the states of Zamfara, Kebbi, Sokoto, Katsina and Kaduna. This has caused strained relationships between communities that share the same ecology, environmental resources and habitat for many generations. Moreover, the state has been unable to apprehend the criminals and resolve this crisis. As a result, the bandits' illegal actions have led to the loss of lives and livelihoods, crippled economic activities, broken social cohesion, and have caused massive displacement of people (Mohammed \& Alimba, 2016:171).

The above scholastic views were also shared equally without any contrast by the informants in their uniformity. Within their various responses, the informants have suggested that the failure of the Nigerian state, in terms of good governance, had led to the outbreak of ownership of arms and weapons by bandits and criminal enterprises for illegal activities. In addition, the theory of 'Securitisation' and 'Social Conflict Theory' also supports the findings of the scholars and interviews by the informants which concludes that the security issue within the region are caused by non-traditional/non-military threats, and the struggles for scarce resources have led to fierce conflicts that compelled some class to device criminal ways to survive, including cattle rustling and banditry.

\section{Ethno-Religious Conflicts}

Ethnoreligious conflict is one of the deadly armed conflicts that have devastated the Northern part of Nigeria for many decades. The ethnoreligious conflict has been identified as the most debilitating issue that have costed countless lives and properties in the region before the 
emergence of the Boko Haram insurgency in Northeastern Nigeria. Thousands of lives and properties were lost, people were displaced, farming was hindered, commercial activities were grounded, infrastructures were destroyed and peaceful co-existence was truncated. Factors that were attributed to the emergence of ethnoreligious conflicts in Northern Nigeria are the political crisis such as inferior governance and manipulation, and socioeconomic conditions such as poverty, corruption, unemployment, inequality, hunger, disease and malnutrition. However, recent studies have indicated that there is no viable factor that had contributed to the consolidation of ethnoreligious conflict in Northern Nigeria, other than the through the distribution of Small Arms and Light Weapons (SALW) across the region in recent years through the Trans-Saharan route (Nowak \& Gsell, 2018:6).

The emergence of SALW in Northern Nigeria had created an avenue for illicit possession of weapons. However, there are no reliable data or statistics on the lives and value of properties that were lost in the ethno-religious conflicts due to the fact that this issue is lasting for many decades in the country. Furthermore, this lingering issue is deduced to have been caused by state negligence, and corruption and manipulation of power in the political arena. Preliminary data obtained since the 1980s have estimated that over 200,000 lives were lost in ethnic and communal religious clashes in different parts of Northern Nigeria, particularly in Kaduna, Bauchi, Plateau, Benue, Taraba, Adamawa, Kano, Sokoto and Nassarawa. The incidences manifested and became more pronounced with the spread and illegal possession of illicit weapons (Nowak \& Gsell, 2018:6).

In an interview with the informants from all categories of the selected informants, most of the informants agreed on the view that the emergence of illicit SALW in Northern Nigeria had created a new dimension that resulted in the ethnoreligious conflicts within the region. For example, one of the informants stated that, "Nigeria has been battling with insecurity in all its characteristics ramifications but the lingering one is the ethnic and religious clashes which has been devouring lives and obliterating wealth across the various parts of the country. The conflicts were escalated and aided like wild bushfire when the SALW illegally found their way into the hands of ethnic militias in Northern Nigeria and extremists 'religious groups that are volatile in nature". Many of the informants shared similar views.

Furthermore, the 'Securitisation Theory' is further supported based on the lack of social cohesion, political unity and economic progress that are considered non-traditional security threats that have led to the armed conflicts in Northern Nigeria, specifically ethnoreligious conflicts. In addition, 'Social Conflict Theory' is also applicable in this perspective because the ethnoreligious conflicts are mostly fueled in Northern Nigeria by politicians who are constantly struggling and competing for power.

\section{Kidnapping}

In recent times, kidnapping has become a rampant social and security issue in Northern Nigeria. The phenomenon is new in Northern Nigeria, however this issue has been going 
on for many decades in the Southern part of the country, especially in the Niger-Delta oil region where business moguls and foreign workers are being kidnapped for ransom. The kidnappers have abducted many notable people for millions of Naira, and recently in dollars for compensation before they release them. This problem became a national security issue in Northern Nigeria since the year 2000. Some of the factors that prompted kidnappings in Northern Nigeria are the easy access to illegal weapons and the resurgence of criminal armed groups in Northern Nigeria. Small Arms and Light Weapons (SALW) are distributed in large quantities across Northern Nigeria more than ever before, and have contributed immensely to various criminal activities that have plagued the region (Nowak \& Gsell, 2018:6).

It is estimated that due to the rampant illicit possession of SALW in Northern Nigeria today, the kidnapping rate has increased significantly to the ratio of an average of 5 for each 100,000 in the region. This indicates that the occurrence of kidnapping is typically synonymous with a dangerous disease that occurs among the populace. All parts of Northern Nigeria are faced with this issue. Traveling from Abuja to Kaduna, Kano to Kaduna, Sokoto to Zamfara, Zamfara to Kebbi, Katsina to Kano, Abuja to Benue and Abuja to Nassarawa are now considered dangerous and risky as these routes have been used by criminals to kidnap foreign workers and tourists. In some cases, the kidnappers would demand for ransom in millions of Naira, whereby negotiations took place for a specified agreed amount. In other circumstances, the kidnappers insisted that their demand must be fully met before they release the victims. The demands vary according to the social status of the abductee. However, in some situations, the kidnappers have killed their captives when the ransom was not paid. In other occasion, once the ransom has been paid, the kidnappers would still kill the captive. There are instances where some armed insurgents would kidnap an important figure and used him to negotiate for either the release of some of their important members, or for other interests (Nowak \& Gsell, 2018:6).

There is a consensus between the informants that were interviewed which suggested that the spread of illegal weapons had subsequently led to the emergence of armed groups and armed conflicts in Northern Nigeria. All of them in their differed opinions expressed different causes of kidnapping in Northern Nigeria that ranged from political, economic, social, cultural, environmental and external factors. However, it should be noted that all the informants had cited the spread of SALW to be one of the main causes that have plagued Northern Nigeria. Additionally, the 'Theory of Securitisation' is applicable in this context because it proposes that social, political, economic and environmental factors are potential threats to security nationally and internationally, and if the issues are not addressed, it would create a security vacuum in the region. 'Social Conflict Theory' is also applicable in this context because the struggles and competition for the control of scarce resources in Northern Nigeria have impoverished some parts of the society who relished retaliation by kidnapping individuals whom they felt are responsible for their present predicaments. The findings are presented as a designed model in Figure 3. 


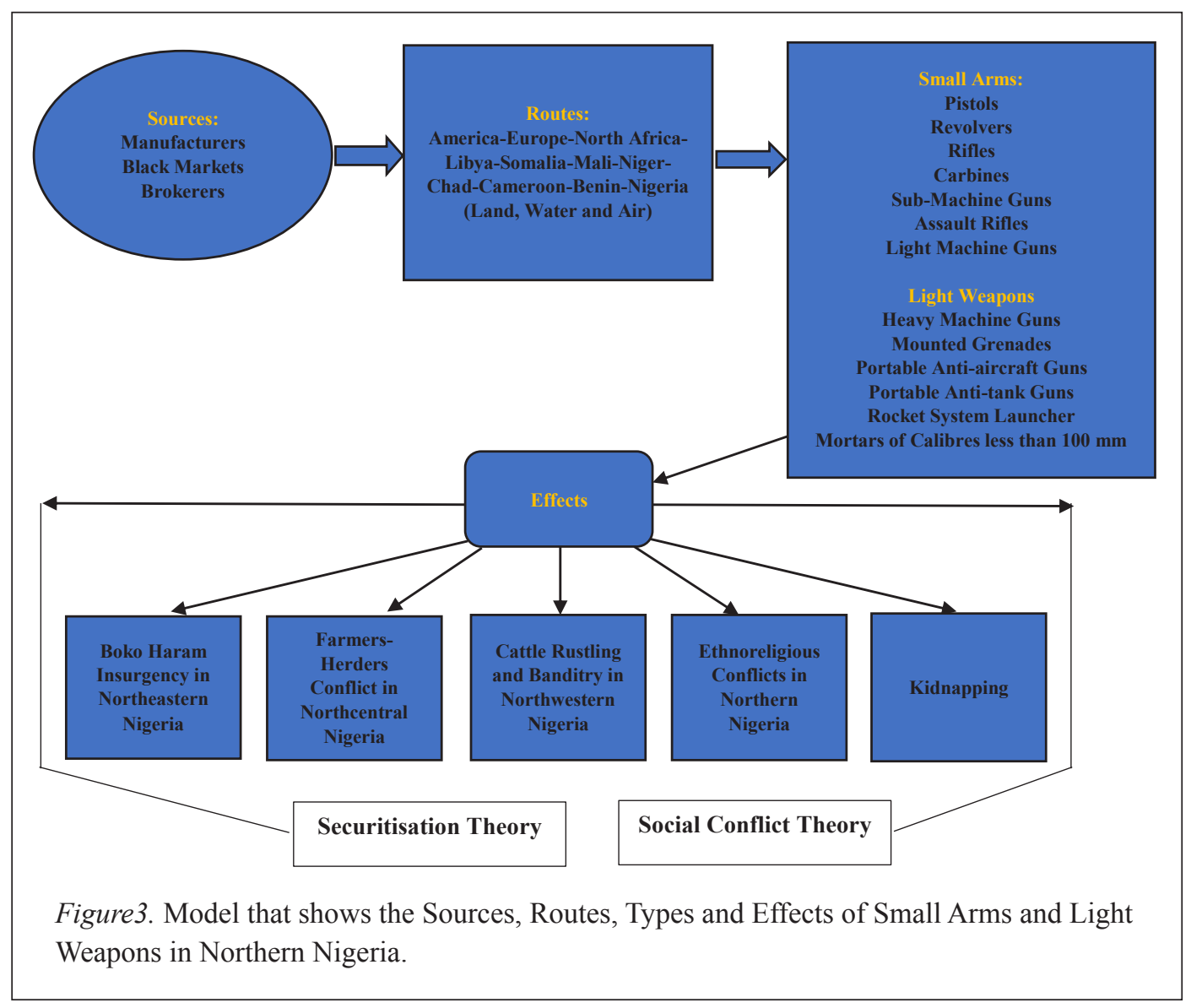

\section{Conclusion and Recommendations}

This study examined the role of Small Arms and Light Weapons (SALW) on the escalation and spread of armed conflicts in Northern Nigeria by employing both the primary and secondary sources to gain a better understanding of its implications. This study highlighted the global spread of weapons illegally that have affected Nigeria through its borders. This has resulted in a multitude of conflicts that affected the people in the region. SALW compounded armed conflicts and instigated criminal activities in Northern Nigeria as manifested in the Boko Haram insurgency in Northeastern Nigeria, farmers-herders conflict in Northcentral Nigeria, cattle rustling and banditry in Northwestern Nigeria, and ethnoreligious conflicts and kidnapping in the entire North. According to this study, the devastating effects can be observed through the loss of thousands of lives, properties worth billions of Naira that were destroyed, people were displaced, farming was hindered, commercial activities were halted, and mutual suspicion was created and sustained among the Nigerian communities. To this end, this study suggests the following recommendations as potential measures that could be taken to address the problem. 
It is recommended that the Nigerian government should establish treaties and agreements on the marking, tracing, brokering and possession of SALW. Security personnel should be trained effectively to develop skills in tracing and containing SALW across the Nigerian borders and within the country. Intelligence gathering should be given priority to identify possession of illegal SALW and illicit weapons. The public should be well informed on the various issues that relate to SALW due to low level of awareness within the public on the spread and impacts of SALW. The Nigerian borders should be monitored and controlled effectively by the Nigerian security personnel to ensure that the illegal SALW do not enter the country. Finally, in the long run, the political and socioeconomic problems of rigging, political violence, inequality, poverty, unemployment, corruption, hunger, disease, illiteracy, malnutrition and deprivation should be immediately addressed through sound micro and macro-economic policies that are sustainable to guarantee a prosperous nation for many Nigerians.

\section{Acknowledgement}

This research received no specific grant from any funding agency in the public.

\section{References}

Aboyade, A. S. (2018). "States' Attitudes to International Boundaries and Africa's Challenging Integration: CUES from Pre-1945 Europe”. In Journal of International Studies. 14(1), 1-21.

Alusala, M. (2016). Lessons from small arms and weapons control initiatives in Africa. BICC Working Paper.

Ashkenazi, M. Beeck, C., \& Isikozlu, C. (2007). Marking and Tracing Small Arms and Light Weapons (SALW). Bonn: Bonn International Centre for Conversion.

Ayissi, A., \& Sall, I. (2005). Combating the proliferation of small arms and light weapons in West Africa. Geneva: United Nations Institute for Disarmament Research.

Bourne, N. (2007). Arming conflicts: The proliferation of small arms. New York: Palgrave Macmillan.

Bowser, E. F., \& Sanders, A. (2012) Security threats in the sahel and beyond: AQIM, Boko Haram and Al Shabab. Civil-Military Fusion Centre; Mediterranean Basin Team.

Buzan, B., \& Hansen, L. (2009). The evolution of international security studies. New York: Cambridge University Press.

Buzan, B. (1983). People, state and fear: An agenda for international security studies in the post-cold war era. Sussex: Great Britain.

Central African Convention for the Control of Small Arms and Light Weapons (2011). Reports on combating of small arms and light weapons. Geneva: United Nations Institute for Disarmament Research (UNIDIR).

Chigozie, C. L. (2010). Nigeria and the ECOWAS convention on small arms and light weapons: A critical appraisal. A Thesis submitted to the Department of Political Science for the award of Master of Science International Relations. University of Nigeria Nsukka. 
D. W. (2017). Flows of Weapons in the Sahel 2011-2017. http://www.dw.org.

Durkin, A. (2019). Global arms trade highest since end of cold war. Hinrich Foundation. https://tradevistas.org/global-arms-trade-highest-since-end-of-cold-war/.

Egbuta, U. (2018). Understanding the farmer-herder conflict in Nigeria. ACCORD: Africa Centre for the Constructive Resolution of Disputes.

Egwu, S. (2016). The political economy of rural banditry in contemporary Nigeria. In Kuna, M. J \& Ibrahim, J. (Eds.) Rural Banditry and Conflicts in Northern Nigeria p.47-69. Abuja: centre of Democracy and Development.

Eloma, U. T., Ugwumba, N. F. C., \& Abang, E. O. (2014). "Effect of proliferation of small arms and light weapons on the development of niger-delta region of Nigeria". Developing Country Studies, 4(10), 60-72.

Farr, V. Myrttinen, H., \& Schnabel, A. (2009). Sexed pistols: The gendered impacts of small arms and light weapons. Tokyo: United Nations University Press.

Forest, J. J. F. (2012) Confronting the terrorism of Boko Haram in Nigeria. Florida: The JSOU Press.

Freeman, F. G. (2018). How big is the international arms trade. Massachusetts: World Peace Foundation.

Gathaga, M. W. (2015). Securing peace in East Africa: Curbing the proliferation of small arms and light weapons in Kenya. A Research Proposal Presented for the Award of Masters Degree of Arts in International Studies. University of Nairobi.

GIABA (2013). The nexus between small arms and light weapons and money laundering and terrorist financing in West Africa. Dakar: ECOWAS.

Gikonyo, J. K. (2012). The illicit proliferation and use of small arms and light weapons and human security in East Africa: A case study of Kenya. A Project Submitted in Partial Fulfillment for the Requirements of Master of Arts in International Conflict Management. University of Nairobi.

Global Policy Forum (2011). How to guide small arms and light weapons proliferation legislation. Geneva: United Nations Development Programme.

Green, O., \& Kirkham, (2009). Preventing diversion of small arms and light weapons: Issues and priorities for strengthened control. University of Bradford: Saferworld.

Holtom, P., \& Pavesi, I. (2018). The 2018 arms trade transparency barometer. Small Arms Survey, Briefings Paper. https://fas.org/asmp/campaigns/smallarms/primer.html

Ikelegbe, A. (2014). "Routes and illegal arms caches between Ghana, Togo, Benin and Nigeria”. In Ohene-Asare, L. S. Aklavon, F. Mossou, T \& Ikelegbe, U. (Eds.). Trafficking of Small Arms and Light Weapons (SALW) in West Africa: Routes between Ghana, Togo, Benin and Nigeria p.93-134. Abuja: Friedrich Ebert Stiftung.

Institute for Peace and Conflict Resolution (2017). 2016 strategic conflict assessment of Nigeria: Consolidated and zonal reports. Abuja: ICPR.

Keili, F. L. (2009). Small arms and light weapons transfer in West Africa: A stockpiling. In United Nations Institute for Disarmament Research (Ed.) The Complex Dynamics of Small Arms in West Africa. Geneva: UNDIR.

Kusa, D. O., \& Salihu, A. (2016) The effects of armed banditry on rural women's livelihood and security: Case study of Kaduna \& Plateau States of Nigeria. In Kuna, M. J \& 
Ibrahim, J. (Eds.) Rural Banditry and Conflicts in Northern Nigeria p.112-167. Abuja: centre of Democracy and Development.

Kwaja, C. M.A., \& Adelehin, B. I. A. (2017). The implication of the open grazing prohibition \& ranches establishment law on farmer-herder relations in the middle-belt of Nigeria. Washington: Search for Common Ground.

Kytomaki, E., \& Yankey-Wayne, V. (2006). Five years of implementing the United Nations programme of action on small arms and light weapons. Regional Analysis of National Report. Geneva: United Nations Institute for Disarmament Research.

Maeresera, S. Rugeje, E. A., \& Zengeni, K. (2018). "The eastern democratic republic of congo recurring conflict: Whose conflict transformation responsibility?". Journal of International Studies. 14(1), 37-49.

Malam, B. (2014). "Small arms and light weapons proliferations and its implications for West African regional security". International Journal of Humanities and Social Sciences, 4(8), 260-269.

Meek, S., \& Stott, N. (2004). A guide to the destruction of small arms and light weapons. The Approach of the South African National Defense Force. Geneva: United Nations Institute for Disarmament Research (INIDIR).

Method, S. (2018). Stemming the tide: African leadership in small arms and light weapons control. https://oefresearch.org/think-peace/african-small-arms-control

Mohammed, K., \& Alimba, C. (2016). Social impact of rural banditry. In Kuna, M. J \& Ibrahim, J. (Eds.) Rural Banditry and Conflicts in Northern Nigeria p.168-189. Abuja: centre of Democracy and Development.

Moses, J. (2017). "Small arms and light weapons proliferation in the $21^{\text {st }}$ century: The Nigerian case”. In International Journal of Development and Sustainability, 6(11), 1638-1652.

Mukhtar, S., Che Rose, R. A., Choy, L. K., \& Bibi-Farouk, A. U. I. (2018). "Boko Haram and the geopolitics of force migration in Nigeria". Journal of International Studies, 14(1), 51-63.

Nowak, M., \& Gsell, A. (2018). Handmade and deadly craft production of small arms in Nigeria. Briefing Paper, Small Ars Survey. German Cooperation.

Nwachukwu, C. A. (2018). Arms proliferation and Nigeria customs. This Day Newspaper. https://www.thisdaylive.com/index.php/2018/09/04/arms-proliferation-and-nigeriacustoms/

Nwosu, C. (2017). Between Fulani Herdsman and farmers: National security under Buhari. The Republic.

Ohene-Asare, L. S., Aklavon, F., Mossou, T., \& Ikelegbe, U. (2014). Trafficking of Small Arms and Light Weapons (SALW) in West Africa: Routes between Ghana, Togo, Benin and Nigeria. Abuja: Friedrich Ebert Stiftung.

Olamide, S. A., \& Emmanuel, A. T. (2018). "Proliferation of small arms and light weapons: The bane of human security in Nigeria". International Journal of Research Publication, 3(1), 1-12.

Olayiwola, S. S. (2017). "Proliferation of small arms and security challenges in Nigeria". International Journal of History and Cultural Studies, 3(3), 33-38. 
Omotosho, M. (2015) "Dynamics of religious fundamentalism: A survey of Boko Haram Insurgency in Northern Nigeria". Journal of Philosophy, Culture and Religion, 4(1), 8-15.

Saferworld (2012). Small arms and light weapons. A Training Manual. Saferworld Publication.

SIPRI Year Book (2018). Armaments, disarmament and international security. Stockholm: SIPRI

SIPRI Year Book (2019). Armaments, disarmament and international security. Stockholm: SIPRI

United Nations (2008). Small arms and light weapons. Selected United Nations Documents. New York: United Nations.

United Nations (2015). Human cost of illicit flow of small arms, light weapons stressed in security council debate. https://www.un.org/press/en/2015/sc11889.doc.htm

United Nations Institute for Disarmament Research (2002). The scope and implications of a tracking mechanism for small arms and light weapons. Geneva: UNIDIR.

United Nations Institute for Disarmament Research (2006). Developing a mechanism to prevent illicit brokering in small arms and light weapons: Scope and implications. Geneva: United Nations.

United Nations Institute for Disarmament Research (2006). European action on small arms and light weapons and explosive remnants of war. Final Report. Geneva: United Nations.

United Nations Institute for Disarmament Research (2008). United Nations action on small arms and light weapons and explosive remnants of war. Final Report. Geneva: United Nations.

United States Institute for Disarmament Research (2006). Tracking and legalising the brokering of small arms and light weapons. Washington: Peace Research publication.

Waziri, R. A., Mat, B. B., \& Taya, S. L. (2018). "Human security under threat: The proliferation of small arms in Nigeria". IOSR Journal of Humanities and Social Sciences, 23(5), 17-21.

Wezeman, P. D. (2018). International arms flow: Monitoring, sources and obstacles. Clingendael: Netherlands Institute of International Relations.

Yacubu, J. G. (2005). Cooperation among armed forces and security forces in combating the proliferation of small arms. In Ayissi, A. \& Sall, I. (2005) Combating the Proliferation of Small Arms and Light Weapons in West Africa p.55-69. Geneva: United Nations Institute for Disarmament Research. 